Physical Therapy Journal of Indonesia (PTJI) 2021, Volume 2, Number 1: 10-15

E-ISSN : 2722-6034; P-ISSN : 2722-0125

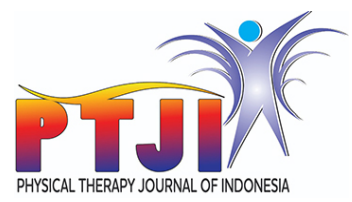

\title{
Training Badminton Footwork Ten Repetitions Two Sets Better Than Five Repetitions Four Sets for The Improvement of Leg Muscle Strength
}

\author{
I Putu Astrawan ${ }^{1 *}$, I Putu Prisa Jaya ${ }^{1}$
}

\begin{abstract}
Background: Footwork training is important in coaching basic movements in badminton. This research aims to learn about the influence of footwork training on improving leg muscles strength. Methods: The study used a randomized pretest-posttest control group design. The participants consisted of 42 male badminton players of Universitas Pendidikan Ganesha, Bali, Indonesia, who split into two groups of footwork training (ten repetitions two sets (group 1) and five repetitions with four sets (group 2)). The coach gave the footwork exercise three times per week for 6 weeks to each group and measured the leg muscle strength using the dynamometer test.
\end{abstract}

Results: The result of the within-group paired T-test before and after the training shows group 1 and group $2(p<0.05)$. For group 1 ,

the mean of leg muscle strength was $114.19 \pm 33.13 \mathrm{~kg}$ before the training and $183.19 \pm 33.56 \mathrm{~kg}$ after the training, with an increase of $60 \%(69 \mathrm{~kg})$. On the other hand, for group 2, the mean score of leg muscle strength before the training was $113.05 \pm 31.30 \mathrm{~kg}$ and after the training was $141.10 \pm 34.91$, with an increase of $25 \%$ ( 28 $\mathrm{kg}$ ). The leg muscle strength difference between the groups before and after the training was tested using the independent $T$-test with a significant $a=0.05$. Comparing the differences of leg muscle strength for both the groups before the training was $p=0.90$, and after the training was $p=0.00$.

Conclusion: The conclusion is training badminton footwork ten repetition two sets better than five repetitions four sets to improve leg muscle strength.

Keywords: badminton, footwork exercise, leg muscles strength.

Cite this Article: Astrawan, I.P., Jaya, I.P.P. 2021. Training Badminton Footwork Ten Repetitions Two Sets Better Than Five Repetitions Four Sets for The Improvement of Leg Muscle Strength. Physical Therapy Journal of Indonesia 2(1): 10-15. D0I: 10.51559/ptji.v2i1.18

'Physical Therapy Department, Universitas Bali International, Bali, Indonesia

*Corresponding author: I Putu Astrawan, Physical Therapy Department, Universitas Bali International, Bali, Indonesia; astraprincepandawa@gmail.com
Received : 2021-02-09 Accepted : 2021-04-28 Published : 2021-05-12

\section{INTRODUCTION}

Footwork is an important movement to produce a quality punch, if it is done in a good position and to be able to hit well, an athlete must be move quickly. The speed of footwork cannot be achieved if the footwork is irregular. ${ }^{1}$ Doing footsteps with high agility requires good physical ability, the earlier an athlete can control their footsteps with high agility, it will be better in anticipating the shuttlecocks. To control good footstep techniques, besides the physical conditions, the ability to control the motion of the lower body parts as well as body movement needs to be considered. In other words, it takes good automation motion to perform footsteps with high velocity. ${ }^{2}$

The previous study by Karyono $(2011)^{2}$ revealed the problem of badminton in Indonesia, among others: (1) the ability of footstep with high leg strength is very important to chase shuttlecock to all corners of the court; (2) technically, footsteps with low of leg power is an obstacle when chasing shuttlecocks in all directions of the court; (3) Indonesian badminton player has obstacles in physical condition, especially footsteps with low of leg power; (4) an appropriate training method is needed to improve the ability of footsteps with low and high speed; (5) appropriate training methods are also needed to improve the ability of footsteps with high strength; (6) the existence of footsteps with different speed and strength level become an obstacle of ability in a badminton game; (7) there is a different opinion about the role of the motor component to the performance of motion in athletes in high skill level (proficient athlete) and low skill level (beginner athlete).

The results of observation during the implementation of achievement coaching badminton took place at the Universitas Pendidikan Ganesha (Undiksha) need to be given special attention on the ground. Among them, the failures that occur in the game are caused by the player was not succeed in controlling bodybuilding and footsteps. Most students do footwork movements perfunctorily, thereby they cannot reach the target of achieving the correct motion. Errors in the implementation of footwork movement will not produce maximum results, either to increase the strength of leg muscles that impact on the fatigue during exercise or match. There is also a decrease in footwork coordination skills during play, seen 
in movements that are less effective and still not coordinated in court practice. In parallel to the problem, more attention is paid to the exercise methods with an alternative to the improvement of the physical condition component, which in this study takes on the effect of footwork training on leg muscle strength as a solution to improve athlete's skill and performance.

According to Grice (2002), ${ }^{3}$ good footwork is performed 20 times. In addition, based on the problems, we conducted a study related to increasing leg muscle strength in badminton players through badminton footwork training consisting of ten repetitions two sets and five repetitions four sets. This study examines the various forms of footwork training methods to improve physical fitness, skill and looks for footwork training which is better for improving leg muscle strength applied in footstep exercises that influence footwork training on leg muscle strength.

The aims of this study are to evaluate the effect of footwork training ten repetitions two sets and footwork five repetitions four sets to increase leg muscle strength and to prove ten-foot repetitions two sets of footwork training better than footwork training five repetitions four sets against the improvement of leg muscle strength among male students of badminton achievement coaching Undiksha in 2016.

\section{METHODS}

This study used randomized pretest-posttest with control group design. ${ }^{4}$ We divided two groups namely group 1 and group 2 , each group consists of 21 participants. Both groups were given an initial test of leg muscle strength $(\mathrm{kg})$. Group 1 was given footwork training ten repetitions two sets and group 2 was given footwork training five repetitions four sets, each training was given for six weeks, with training frequency three times a week i.e. Monday, Wednesday, and Friday. Morning training time was 07.30-09.00 A.M. and afternoon training was 04.30-06.00 P.M. was held at Sports Building of the Faculty of Sport and Health Undiksha and Santo Paulus Singaraja Sports Building, from February 15 to April 8 in 2016. The benefits received by the study participants were increased leg muscle strength due to badminton footwork training. The risk that the study participants likely experienced were a minor injury to the leg area such as muscle pain. Yet, no need to worry about the injury because the body will adapt to the training given. We provided the recovery time or rest time to regenerate the body to return it in maximum function.

We chose male students of achievement coaching badminton of Undiksha of the 2016 school year as the participant in our study, in total there are 50 students who fulfilled the criteria of inclusion and exclusion. The ordinal pairing technique is a method of dividing the research sample into several groups in order to have the same ability, it aims to maintain the homogeneity or similarity between the treatment group and the appeal group. ${ }^{5}$ The research sampling technique is simple random sampling. We found 42 students were taken as research samples and divided into two groups by ordinal pairing, and each group was 21 participants.

Badminton footwork training ten repetitions two sets is a physical training of badminton with movements of the footsteps that regulate the body to all corners of the court for controlling and positioning the body in such a way as to facilitate the movement of hitting the shuttlecock according to its position. The goal is touching the angles of the court, as much as 20 times (ten repetitions two sets in 20-30 seconds per set, inter break for 30 seconds). The footsteps movement to the corner of the court two to six steps. While training footwork five repetitions four sets is a physical training of badminton footsteps movement for controlling and positioning the body in such a way to all angles of the court so as to facilitate the movement to hit the shuttlecock according to the position. The goal is touching the angle of the court, as much as 20 times (five repetitions four sets in 20 to 30 seconds per set, inter break for 30 seconds), while the movement of the footsteps to the court is the same as the opposite group. Leg muscle strength is the ability of a muscle or muscle group to overcome a burden of resistance. To measure the ability of leg muscle strength, we used a leg dynamometer. The amount of leg muscle strength that can be seen in the tool and recorded the number or value of most of the three forces performed.

The data obtained were analyzed with the help of a statistic program service solution (SPSS) 16.0 at the significance level $\alpha=0.05$. The difference of training effect in this study was tested with paired sample $T$-test and independent sample $T$-test which was preceded by normality and homogeneity test. Paired samples $T$-test was used to analyze differences in intra-group leg muscle strength results before and after training in both treatment groups because the data were normally distributed and homogeneous. The meaning limit of $\alpha=0.05$. Independent samples $T$-test was used to analyze differences in leg muscle strength results between treatment groups, both before and after treatment. The analysis was considered significant if the $p$-value was $<0.05$. 


\section{RESULTS}

The characteristics of the samples analyzed include; age, height, weight, and body mass index were represented in Table 1. Those results showed no significant difference between age, height, body weight, and body mass index of the two groups

Table 1. Physical characteristics of students

\begin{tabular}{|c|c|c|c|c|c|c|}
\hline \multirow{2}{*}{ Characteristics } & \multicolumn{3}{|c|}{ Group 1} & \multicolumn{2}{|c|}{ Group 2} & \multirow[t]{2}{*}{$P$} \\
\hline & $\mathbf{N}$ & Mean & SD & Mean & SD & \\
\hline Age (year) & 21 & 20.71 & 1,27 & 20.14 & 1.06 & 0.12 \\
\hline Height (cm) & 21 & 169.00 & 5.08 & 168.00 & 5.78 & 0.32 \\
\hline Weight (kg) & 21 & 64.19 & 6,68 & 62.00 & 8.44 & 0.35 \\
\hline Body Mass Index & 21 & 22.25 & 1,62 & 22.16 & 2.96 & 0.48 \\
\hline
\end{tabular}

Table 2. Normality and homogeneity results of leg muscle strength data pre- and post-training

\begin{tabular}{|c|c|c|c|c|}
\hline \multirow[t]{2}{*}{ Variable } & \multirow[t]{2}{*}{ Training } & \multicolumn{2}{|c|}{$\begin{array}{l}\text { (P) Normality test } \\
\text { (Shapiro Wilk test) }\end{array}$} & \multirow{2}{*}{$\begin{array}{c}\text { (P) Homogeneity } \\
\text { test (Levene } \\
\text { test) }\end{array}$} \\
\hline & & Group 1 & Group 2 & \\
\hline \multirow{2}{*}{$\begin{array}{l}\text { Leg muscles strength } \\
(\mathrm{kg})\end{array}$} & Before & 0.95 & 0.83 & 0.82 \\
\hline & After & 0.95 & 0.28 & 0.98 \\
\hline
\end{tabular}

Table 3. Mean differential strength of leg muscles pre- and postintergroup training

\begin{tabular}{lcccc}
\hline Leg muscles strength $(\mathbf{k g})$ & $\mathbf{N}$ & Mean \pm SD & $\mathbf{T}$ & $\boldsymbol{P}$ \\
\hline Group 1 & & & & \\
$\quad$ Before training & 21 & $114.19 \pm 33.13$ & -16.85 & 0.00 \\
$\quad$ After training & & $183.19 \pm 33.56$ & & \\
Group 2 & & & & \\
$\quad$ Before training & 21 & $113.05 \pm 31.30$ & -7.37 & 0.00 \\
$\quad$ After training & & $141.10 \pm 34.91$ & & \\
\hline
\end{tabular}

Table 4. The improvement of leg muscle strength pre- and postintergroup training

\begin{tabular}{lllcll}
\hline \multirow{2}{*}{ Variable } & \multirow{2}{*}{ Training } & \multicolumn{2}{c}{ Mean \pm SD } & \multirow{2}{*}{ T } & $\boldsymbol{P}$ \\
\cline { 3 - 4 } & & Group 1 & Group 2 & & \\
\hline Leg muscles & Before & $114.19 \pm 33.13$ & $113.05 \pm 31.30$ & 0.11 & 0.90 \\
strength $(\mathrm{kg})$ & After & $183.19 \pm 33.56$ & $141.10 \pm 34.91$ & 3.98 & 0.00 \\
\hline
\end{tabular}

Table 5. Percentage of leg muscle strength

\begin{tabular}{|c|c|c|}
\hline $\begin{array}{l}\text { Leg muscles strength } \\
\text { (kg) }\end{array}$ & $\begin{array}{c}\text { Group 1 } \\
\text { (Footwork ten } \\
\text { repetitions two sets) }\end{array}$ & $\begin{array}{c}\text { Group 2 } \\
\text { (Footwork five } \\
\text { repetitions four sets) }\end{array}$ \\
\hline Before Training (T1) & 114,19 & 113,05 \\
\hline After Training (T2) & 183,19 & 141,10 \\
\hline $\begin{array}{l}\text { Increase Difference (T2- } \\
\mathrm{T} 1)\end{array}$ & 69 & 28,05 \\
\hline Percentage Increase & $60 \%$ & $25 \%$ \\
\hline
\end{tabular}

before the training $(p>0.05)$, thereby each group has the same physical character and ability. Table 2 shows that the data was normally distributed so that further tests using a parametric statistic test. Normality test by Shapiro-Wilk test shows that the data is normally distributed. The Levene test shows that the data is homogeneous $(p>0.05)$.

Table 3 shows that the average strength of leg muscle pre-and post-training between the two groups has a $p$-value smaller than 0.05 . This shows that the mean muscle strength of the leg after training in each group has a significant difference $(p<0.05)$. Thus, the difference in the average of leg muscle strength pre-training between group 1 and group 2 was comparable. The difference in leg muscle strength after training was significantly different, which means the difference in the outcomes was due to differences in repetition and set in the training of each group. The average muscle strength of the leg between pre-and post-training in group 1 and group 2 had a $p$-value less than 0.05 . It means that groups 1 and group 2 have a significant difference in leg muscle strength between pre-and post-training. Hence the proven hypothesis, badminton footwork training ten repetitions two sets and five repetitions of four sets can increase leg muscle strength.

To determine the increase in leg muscle strength between the two groups both pre-and post-training. Table 4 shows that the mean leg muscle strength pre-training between the two training groups has a $p$-value greater than 0.05 , whereas after training has a $p$-value of less than 0.05 . This means that the mean leg muscle strength data pre-training between the two groups did not differ significantly $(p>0.05)$. Thus, the mean leg muscle strength pre-training is comparable. While the difference in leg muscle strength after training was significantly different $(p<0.05)$, meaning the result of leg muscle strength between group 1 and group 2 was significantly different.

After six weeks of training, there is a difference in the increase and percentage. The percentage increase in leg muscle strength in both groups, use the following formula: $\mathrm{P}=(\mathrm{T} 2-\mathrm{T} 1) / \mathrm{T} 1 \mathrm{x} 100 \%{ }^{6}$

Table 5 shows that the increased muscle strength of the leg after training in group 1 was greater than in group 2. This showed that both treatment groups had an increased effect after being given footwork training. The percentage increase in leg muscle strength in group 1 training gave a better impact than group 2 training. Hence the hypothesis was proved where the improvement that occurred in group 1 with footwork training ten repetition two sets was better than group 2 who did footwork training five repetitions four sets in boost leg muscles increase. 


\section{DISCUSSION}

The effect of badminton footwork training ten repetitions two sets can improve leg muscle strength. The increased ability of leg muscle strength in each group is caused by badminton footwork training, this is reasonable because the training is carried out for six weeks with a frequency of three times a week in accordance with the recommended training dose so as to enable the beneficial ability of leg muscle strength where there is an adaptation of muscle contraction to the giving of weight given during the training. Training provided within 6-8 weeks will have a constant result, in which the body has been adapted to the training. ${ }^{\text {? }}$

Footwork training is training that prepares leg and leg muscles to work more effectively and efficiently. Robust muscle activity causes muscle size to increase. The diameter of each muscle fiber increases, sarcolemma increases, and the fibers get the nutrients and metabolic intermediates such as adenosine triphosphate, keratin phosphate, mitochondrial interstellar lipid glycogen increases, myofibril also increase in number and size. Muscle hypertrophy improves muscle strength and nutrient mechanisms to maintain increased mobility. Muscle activity is very strong although only a few minutes occur every day. Long muscle activity increases muscle endurance, leading to an increase in oxidative enzymes, myoglobulins, and blood capillaries that are essential for increased muscle metabolism. ${ }^{8}$

Physical training that is applied systematically, regularly, and measurably with sufficient dosage and time, will lead to physiological changes that lead to greater energy-producing ability and improve physical appearance. The proper types of physical training will provide changes that include anaerobic substrate enhancement such as adenosine triphosphate-phosphocreatine (ATP-PC), creatine, and glycogen as well as an increase in the amount and activity of enzymes in metabolic processes in the body. The effect of regular training will lead to muscle hypertrophy, this is due to the number of myofibrils, fibrils size, capillary vessel density, nerves, tendons, ligaments and total contractile amounts especially myosin contractile proteins increased proportionally. Changes in muscle fibers do not all occur at the same rate, a greater increase occurs in white muscle fibers (fast-twitch) resulting in increased muscle contraction velocity. ${ }^{9}$

In muscle strength training, increased muscle strength was initially caused by improved motor nervous system controls such as alignment of motor unit recruitment, decreased autogenous inhibition of Golgi organ tendons, agonist muscle coagulation, and antagonists as well as motor impulse frequency to motor units. Structural changes may occur as a result of strength training, both in the neuromuscular junction and in muscle fibers. Muscle enlargement, also called muscle hypertrophy can occur as a result of muscle strength training. In hypertrophic muscle, there is an increase in the number of myofibrils, actin filaments and myosin, sarcoplasm, and other supporting tissues. ${ }^{10}$

Footwork training ten repetitions two sets has a type of workload centered on the movement of step foot to the corner of the court involving leg muscles and done repeatedly that will provide stress on the leg muscle component so that the leg muscles have muscle hypertrophy. Muscle hypertrophy is caused by an increase in the number and size of muscle cells and fibers. Through an increase in the size and number of leg muscle fiber cells, it will increase leg muscle strength. ${ }^{11}$

The effect of badminton footwork training five repetitions four sets can improve leg muscle strength. Effect of badminton footwork training five repetitions four sets on leg muscular ability mainly occurs in motor units (nerves and muscles), coordination of antagonistic muscle contractions, and synchronization in training. Neural adaptations increase strength and improve coordination. The proper type and dose of training will have a beneficial impact on the athlete. Trained athletes will look like mild but strong and graceful movements. This movement, due to neural coordination control of muscle movement, with increased contractile capacity and synchronization in the release of energy from elastic components in muscle cells. This nerve adaptation includes reflex motor units for contraction, improved coordination of antagonist muscle groups, and decreased inhibition of the Golgi tendon organ. ${ }^{7}$

Assessment of the ability of muscle work is the maximum strength of muscles that produce a force on a muscle contraction, also called muscle strength and muscle endurance in maintaining contraction (muscle work), called muscle endurance. Skeletal muscle demonstrates great changeability or plasticity in responding to various forms of training. This plasticity is a different adaptation of contraction activity due to different forms of exercise, which in this case is strength training. At the cellular level, exercise adaptation can be seen as the accumulation of a number of proteins whose main cause is the change in gene expression. At the organ level, these differences appear as skeletal muscles of different characteristics. ${ }^{10}$

During the anaerobic physical training in this case the badminton footwork training, the depleted energy reserves are ATP and PC, so in ATP and PC 
spare foot ATP training steps run out after stepping a few seconds with high speed. Recovery of anaerobic physical energy training is charging ATP and PCs in the muscle that has been drained during activity. The break interval is the time between the work interval or set. The purpose of rest is for recovery after doing work. ${ }^{12}$ The ability of the circulatory system to transport blood from the inactive part to the active part and the ability of the tissue to absorb the blood is illustrated by the difference in blood oxygen content of the arteries and veins. The effect of exercise on blood volume depends on the type of training, intensity, state, and acclimatization in an area. Athletes able to drain most of their blood to the muscles that are working during the course of the training will have a significant difference in blood content between the arteries and veins, since the active muscle absorbs more oxygen from the blood, rather than inactive tissues. ${ }^{13}$

Badminton players who have muscle capacity with more mitochondria will be better able to absorb oxygen from the blood. In the optimal training footwork five repetitions four sets, hypertrophy is seen in both slow-twitch (ST) and fast-twitch (FT) muscle fibers. The form of badminton footwork training results in the second hypertrophy of the muscle fibers so that the number of mitochondria increases and automatically increases the process of oxygen uptake and muscle strength. ${ }^{12}$ Badminton footwork training ten repetition two better set compared five repetitions four sets to increase leg muscle strength. Muscle strength is more effective to be given the burden of exercise above its ability. It aims to adapt the functional body, so as to increase muscle strength. Exercises that use weight training below or above the ability will only keep the strength to remain stable, but will not increase it. With this principle of excess burden, the muscle groups will develop their strength effectively. Increasing the load performed must be heavier than the previous practice on the threshold of sensitivity. The application of the load-increasing system is called progressive overloading. By the time the athlete has been strong, the heavy load will feel light. The loading of working muscles should be increased gradually during the exercise program by counting the number of repetitions that can be performed before the fatigue. Muscles will work on areas slightly above their abilities called by the principle of gradual improvement. ${ }^{14}$

Based on research to increase muscle strength, with a volume of two to ten repetition maximum in one to three sets, with density or frequency of two to four times a week gives better results. The training dosage to increase muscle strength to work well is high intensity (70 to $100 \%$ ) with low volumes training (six to ten repetition and three to five sets) and frequency (two to three times a week). ${ }^{7}$ In this case, it is very appropriate for training ten footwork repetition two sets in improving muscle ability. Compared with the five footwork training of four repetitions, the exercise volume is five repetitions, four sets with three times a week, then with low intensity and high volume (repetition and set), the resulting increased muscle endurance. ${ }^{7}$ So very proper training badminton footwork ten repetitions two sets with $80 \%$ training intensity to increase leg muscle strength because it includes high intensity resulting in increased muscle strength. ${ }^{14}$ In training footwork, ten repetitions four sets with high volume, low intensity, and frequency of exercise three times a week is perfect for improving leg muscle endurance.

The system set is a weight training by doing some repetition of a form of exercise which is then interspersed with breaks every set. Originally, the number of repetitions sets in this study is two sets of ten repetitions. Training program with a set system for several muscle groups as follows: 1 ) sets $I=10$ repetitions at load $50 \%$ of load weight; 2 ) sets II = 10 repetitions at load $75 \%$ of load; 3 ) sets III $=10$ repetition at full load. ${ }^{14}$ The implementation of the progressive overloading system in this study used the training load of two sets of ten repetitions at 75\% load where the weight of the exercise was not too heavy that the athlete could not possibly overcome because it could damage the body's physiological system or could cause sports injury.

Better training of badminton footwork ten repetitions two sets of five repetitions four sets in increasing leg muscle strength can be caused by set differences and repetition during training that will affect the energy consumption during exercise. Therefore, the weight of the body load required in the ten-second repetition football ten badminton training sets is greater than the five repetitions of four sets. The difference in weight-weighted use during training led to the adaptation of the body's physiological responses to the training given that recurrent stretching of the muscles caused a greater contraction or impetus in accordance with the principle of excess burden. ${ }^{15}$ Then, group 1 becomes more effective than group 2 in improving the ability of leg muscle strength, because the sample of study in group 1 has the opportunity to move more step by holding the weight of the body load longer so that the body will adapt to the treatment. While the study sample in group 2, performs the same footstep movement but the shorter repetition of each set, which holds the lighter weight of the body so that it adapts to the weight given during the training. This factor leads to a larger group 1 training burden and 
more specific and maximum training than in group 2.

The results of this study are supported by Setiyoko in 2013 stated that there is an effect of leg press training plyometric on increasing leg muscle strength and jump height and shows that there is a difference in influence between the intervention group with the control group. ${ }^{16}$ Playing badminton has an effect on increasing speed, muscle strength, and agility, in accordance with the principles of training, it will have a physiological effect on skill levels, and this change will have an impact on increasing player skills so that they can easily reach the shuttlecock across the field. ${ }^{17}$

\section{CONCLUSION}

We concluded that footwork training in badminton with ten repetitions two sets increase leg muscle strength, as well as five repetitions four sets. Further, ten repetitions two sets better than five repetitions four sets in order to increase leg muscle strength in male students of achievement coaching badminton Undiksha academic year 2016.

\section{CONFLICT OF INTEREST}

The author states there is no potential conflict of interest in connection with the research, authorship and or publication of this article.

\section{FUNDING}

This study was not funded by any grant source.

\section{AUTHOR CONTRIBUTIONS}

IPA carried out the study design, data collection, and drafting the article; IPPJ conceived the study design, data interpretation, and drafting the article.

\section{REFERENCES}

1. Yoniel Y. Metode Pelatihan Distributed Practice Lebih Efektif Dari Pada Massed Practice Dalam Meningkatkan Kecepatan Smash Bulutangkis Pada Mahasiswa Semester VIII Universitas PGRI NTT: Tesis). Denpasar: Universitas Udayana; 2013.
2. Karyono T. Pengaruh Metode Latihan dan Power Tungkai Terhadap Kelincahan. Studi Eksperimen) Yogyakarta: Universitas Negeri Yogyakarta Fakultas Ilmu Keolahragaan. 2011.

3. Grice T. Bulu tangkis: petunjuk praktis untuk pemula dan lanjut: PT RajaGrafindo Persada; 1996.

4. Pocock SJ. Clinical trials: a practical approach: John Wiley \& Sons; 2013.

5. Kanca IN. Metode Penelitian Pengajaran Pendidikan Jasmani dan Olahraga. Singaraja: Universitas Pendidikan Ganesha; 2010.

6. Arikunto S. Dasar-dasar Evaluasi Pendidikan (edisi revisi). 2019.

7. Nala I. Prinsip Pelatihan Fisik Olahraga. Denpasar. Universitas Udayana. 2011.

8. Syaifuddin $\mathrm{H}$, editor Anatomi Fisiologi; Kurikulum Berbasis Kompetensi2011: EGC.

9. Hairy J. Buku Materi Pokok Dasar-Dasar Kesehatan Olahraga. Jakarta: Depdikbud. 2009.

10. Sudarsono NC. Pengaruh Latihan Terhadap Kerja Otot Rangka. Jakarta: Departemen Ilmu Faal Fakultas Kedokteran Universitas Indonesia. 2006.

11. Hanafi S. Efektifitas latihan beban dan latihan pliometrik dalam meningkatkan kekuatan otot tungkai dan kecepatan reaksi. Jurnal Ilara. 2010;1(2):1-9.

12. Ratmin S. Pengaruh pelatihan fisik anaerob terhadap peningkatan volume oksigen maksimal pemain sepakbola. Jurnal penjakora. 2017;2(1):39-50.

13. Budiawan M. Peningkatan kadar haemoglobin darah sebagai dampak pemberian sulfas ferrosus pada atlet bola basket usia 17-20 tahun. Jurnal Sangkareang Mataram. 2017;3(2):31-3

14. Chan F. Strength Training (Latihan Kekuatan). Cerdas Sifa Pendidikan. 2012;1(1).

15. Laksana I. Pelatihan Melompati Rintangan Setinggi 60 $\mathrm{cm}$ Lebih Baik Dibandingkan Rintangan Setinggi $30 \mathrm{~cm}$ Untuk Meningkatkan Ketepatan Jumping Smash Pemain Bulutangkis SMK Negeri 2 Kuripan Lombok Barat: Tesis). Denpasar: Universitas Udayana; 2015.

16. Setiyoko P, Wahyuni S, Widodo A, Fis S. Pengaruh Latihan Plyometrik Leg Press Training Terhadap Peningkatan Kekuatan Otot Tungkai Dan Tinggi Lompatan Pada Pemain Bola Basket Di SMPN 26 Surakarta: Universitas Muhammadiyah Surakarta; 2013.

17. Gunawan E. Pengaruh Pelatihan Footwork Tenis Meja Terhadap Kecepatan Reaksi dan Kelincahan Pada Siswa Putra Kelas VII SMP Negeri 2 Denpasar Tahun Pelajaran 2013/2014. Skripsi) Singaraja: Universitas Pendidikan Ganesha. 2013.

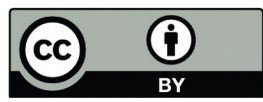

This work is licensed under a Creative Commons Attribution 